\title{
Tiger Swallowtail, Eastern Tiger Swallowtail, Papilio glaucus Linnaeus (Insecta: Lepidoptera: Papilionidae) ${ }^{1}$
}

\author{
Donald W. Hall and Jerry F. Butler ${ }^{2}$
}

\section{Introduction}

The eastern tiger swallowtail, Papilio glaucus Linnaeus, is probably our most recognizable swallowtail in the eastern United States. It is admired by butterfly gardeners and treasured by young butterfly collectors. The first drawing of a North American swallowtail was of a male tiger swallowtail and was drawn in 1587 by John White, who was commander of Sir Walter Raleigh's third expedition to North America (Holland 1949; Opler and Krizek 1984). The eastern tiger swallowtail's popularity is evident from its use on two US postage stamps (Figure 1).
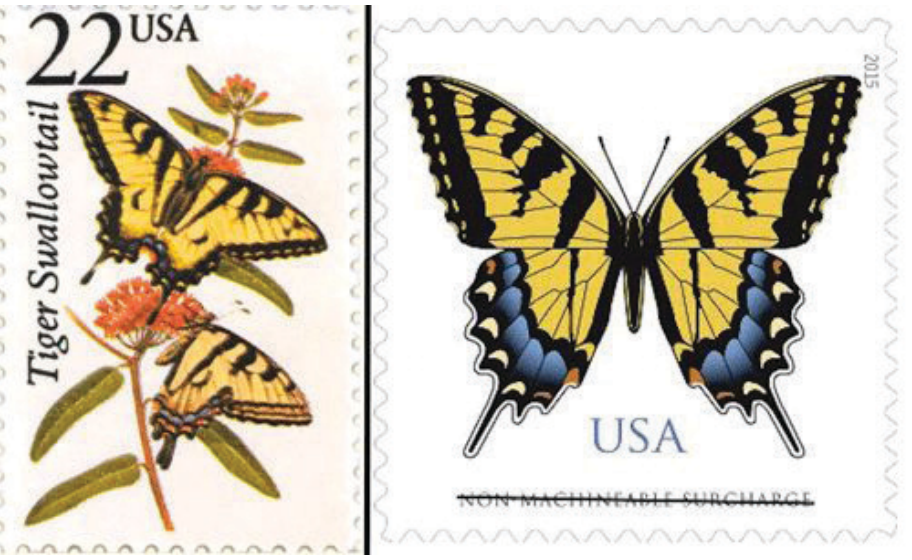

Figure 1. US postage stamps featuring eastern tiger swallowtails, Papilio glaucus Linnaeus.

Credits: Jerry F. Butler, UF/IFAS

\section{Nomenclature}

Linnaeus grouped some swallowtails and other butterflies under the genus name Papilio (Tyler 1975). Papilio is the Latin word for butterfly. The subgenus name Pterourus is from the Greek roots "ptero" for wing and "ura" for tail (Borror 1960).

There is disagreement on the generic classification of the swallowtails (Hancock 1983, Miller 1987). Some authors (e.g., Tyler et al. 1994; Minno et al. 2005) follow the system that elevates the subgenus Pterourus to generic status as proposed by Hancock (1983). Because the name Papilio is still so widely used in sources available to the public, it will be used here instead of Pterourus for practical reasons.

\section{Distribution}

The eastern tiger swallowtail is widely distributed from New England west through the southern Great Lakes area and most of the Great Plains states (with a few records from Colorado) and south to Texas and Florida (Figure 2). In the northern United States and southern Canada, the eastern tiger swallowtail is sympatric (occurring within the same geographical area) with the closely related Canadian tiger swallowtail, Papilio canadensis, which was once considered a subspecies of Papilio glaucus (e.g., Emmel 1975, Scott 1986). Within this sympatric zone, some hybrids occur (Hagen et al. 1991).

1. This document is EENY-61, one of a series of the Entomology and Nematology Department, UF/IFAS Extension. Original publication date October 1998. Revised May 2007 and May 2020. Visit the EDIS website at https://edis.ifas.ufl.edu. This document is also available on the Featured Creatures website at http://entnemdept.ifas.ufl.edu/creatures/.

2. Donald W. Hall, professor; and Jerry F. Butler, professor, Entomology and Nematology Department; UF/IFAS Extension, Gainesville, FL 32611.

The Institute of Food and Agricultural Sciences (IFAS) is an Equal Opportunity Institution authorized to provide research, educational information and other services

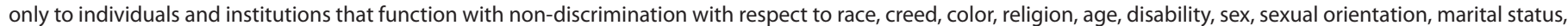

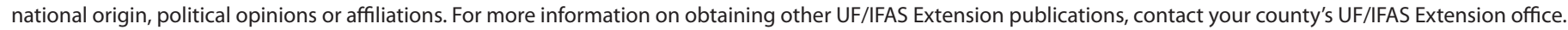
U.S. Department of Agriculture, UF/IFAS Extension Service, University of Florida, IFAS, Florida A \& M University Cooperative Extension Program, and Boards of County Commissioners Cooperating. Nick T. Place, dean for UF/IFAS Extension. 


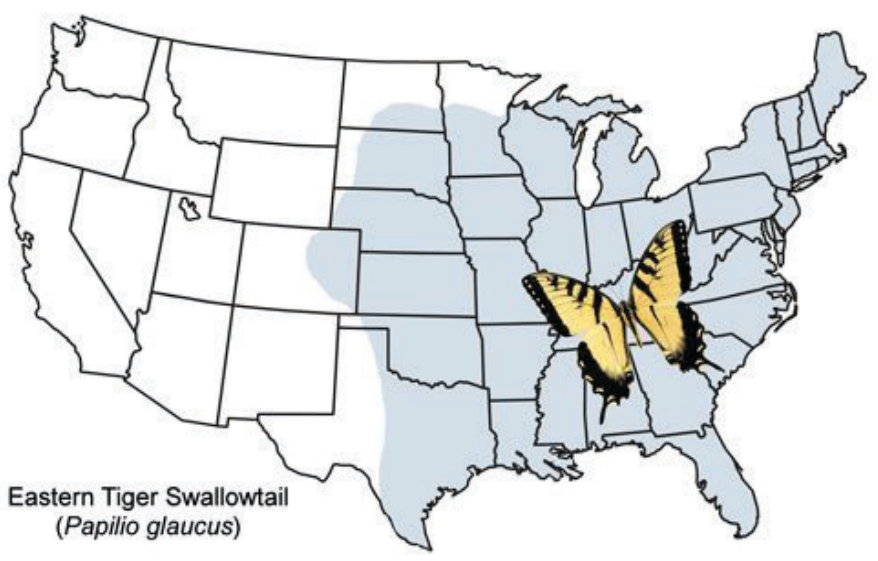

Figure 2. Distribution map of Papilio glaucus Linnaeus. Credits: Jerry F. Butler, UF/IFAS

\section{Description}

\section{Adults}

The eastern tiger swallowtail is a large species with a wingspread range of 7.9 to $14.0 \mathrm{~cm}$ (approx. 3.12 to 5.5 inches) (Pyle 1981). Adults are yellow with four black bands on the front wings (Figures 3 and 4). The innermost band lines up with the median band of the hind wing. The wing margins are black with a row of yellow spots.

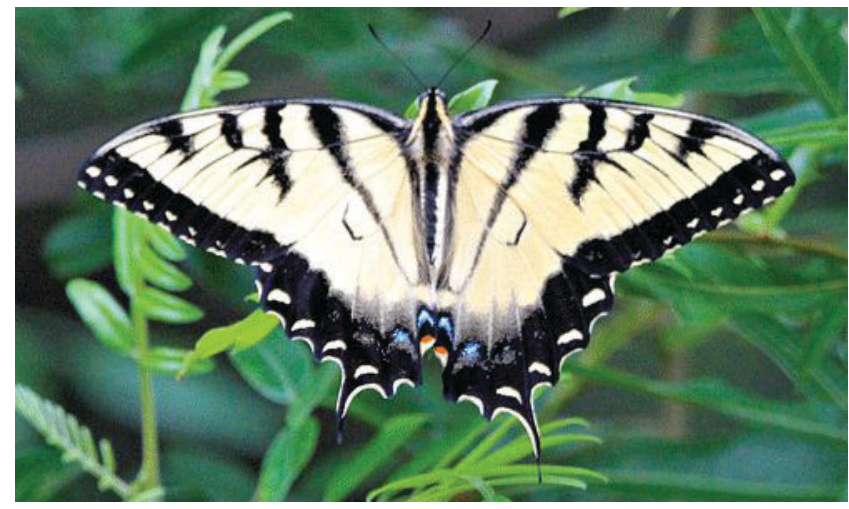

Figure 3. Adult tiger swallowtail, Papilio glaucus Linnaeus (wings spread, showing dorsal surface).

Credits: Donald W. Hall, UF/IFAS

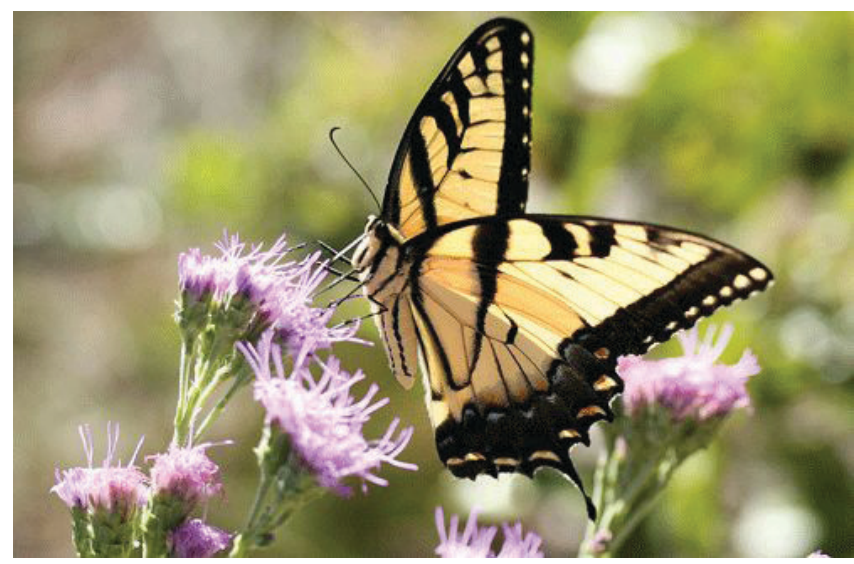

Figure 4. Adult tiger swallowtail, Papilio glaucus Linnaeus (wings folded, showing ventral surface).

Credits: Donald W. Hall, UF/IFAS
Some female tiger swallowtails are dark colored with a marginal row of yellow spots (Figure 5). Faint remnants of the typical tiger swallowtail stripes are visible on the undersides of the front wings of the dark form (Figure 6). The hind wings of the dark form are powdery-blue above with a wavy black band dividing the powdery blue areas. This band is absent in female spicebush swallowtails, Papilio troilus L., which may otherwise superficially resemble dark tiger swallowtails. In addition, the marginal spots of Papilio troilus are typically blue-green rather than yellow.

In butterflies, the sex chromosomes are the opposite of those in mammals. Female butterflies are the heterogametic sex (XY), and males are homogametic (XX). Yellow Papilio glaucus females give birth to yellow females, and dark females give birth to dark females indicating that the gene for color is on the Y chromosome (Scriber et al.1995).

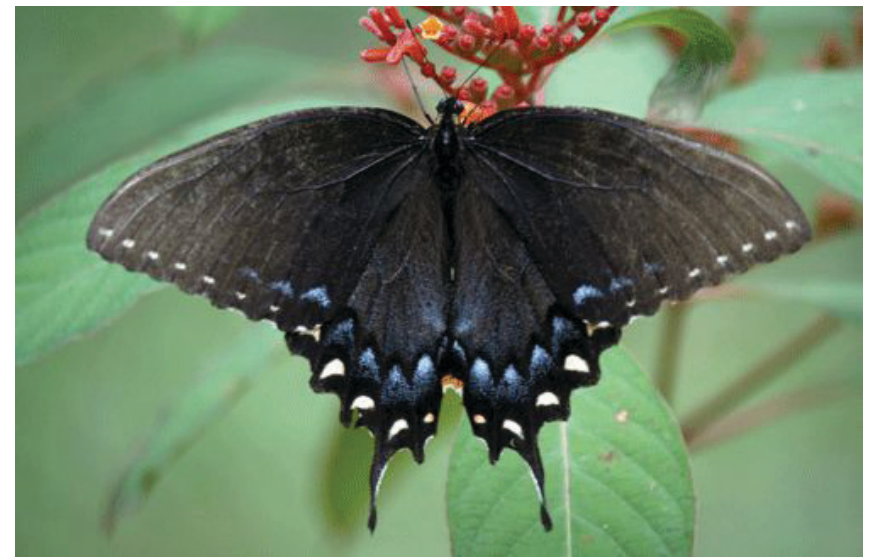

Figure 5. Dark female tiger swallowtail, Papilio glaucus Linnaeus (wings spread, showing dorsal surface).

Credits: Donald W. Hall, UF/IFAS

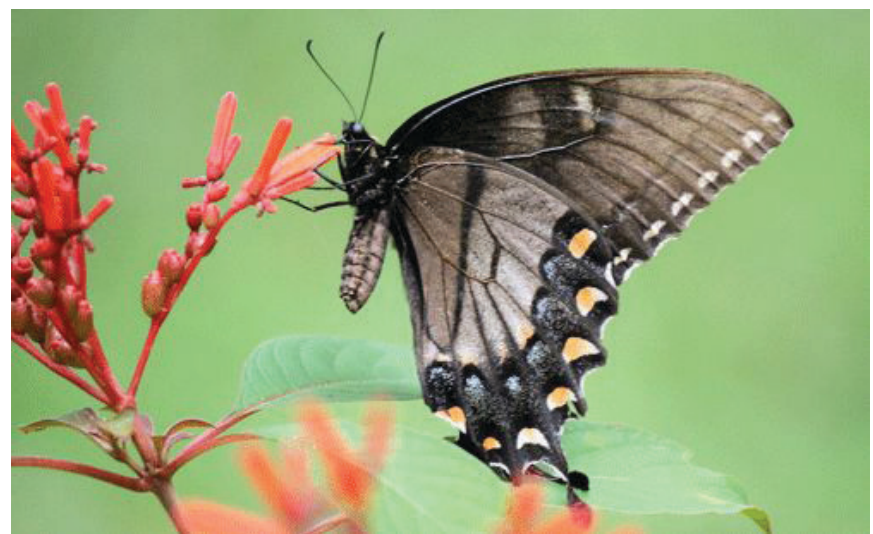

Figure 6. Dark female tiger swallowtail, Papilio glaucus Linnaeus (wings folded, showing ventral surface with characteristic stripes). Credits: Donald W. Hall, UF/IFAS

The dark females are considered to be Batesian (edible) mimics of the poisonous pipevine swallowtail, Battus philenor (L.) (http://entnemdept.ufl.edu/creatures/bfly/ pipevine_swallowtail.htm) (Brower 1958). 


\section{Eggs}

Eggs are green (Minno and Minno 1999).

\section{Larvae}

Full-grown larvae range up to $6.4 \mathrm{~cm}$ (approx. 2.5 inches) in length (Minno et al. 2005). The first three instars are dark brown with a white saddle and resemble bird droppings (Minno and Minno 1999; Wagner 2005). Fourth and fifth instar larvae are green with a swollen thorax and a transverse band of faint blue dots on each abdominal segment (Figures 7 and 8). There is a black transverse stripe edged with yellow anteriorly between the first and second abdominal segments that is usually hidden from view in the segmental fold. Larvae also have a single pair of false eyespots on the metathorax. The eyespots are yellow ringed with black and contain a smaller blue spot lined with black and a black line mesad (toward the midline of the back) of the blue spot. The osmeterium is orange (Minno et al. 2005). Fourth instar larvae retain the white saddle (Figure 7).

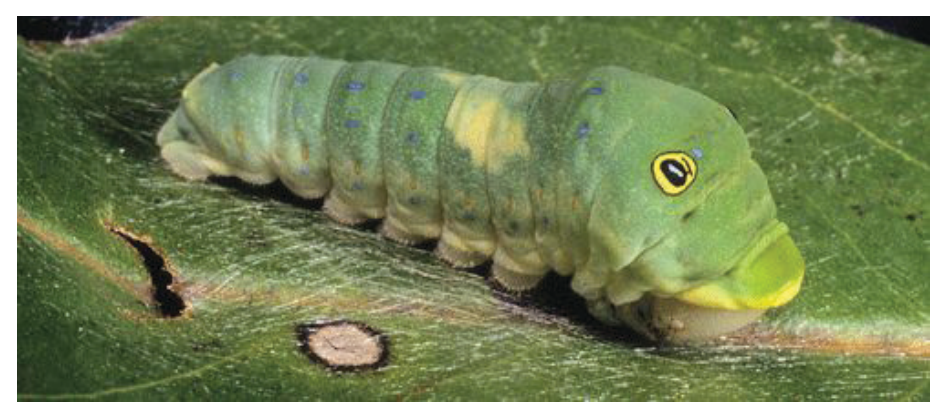

Figure 7. Fourth instar larva of the tiger swallowtail, Papilio glaucus Linnaeus showing the white saddle.

Credits: Donald W. Hall, UF/IFAS

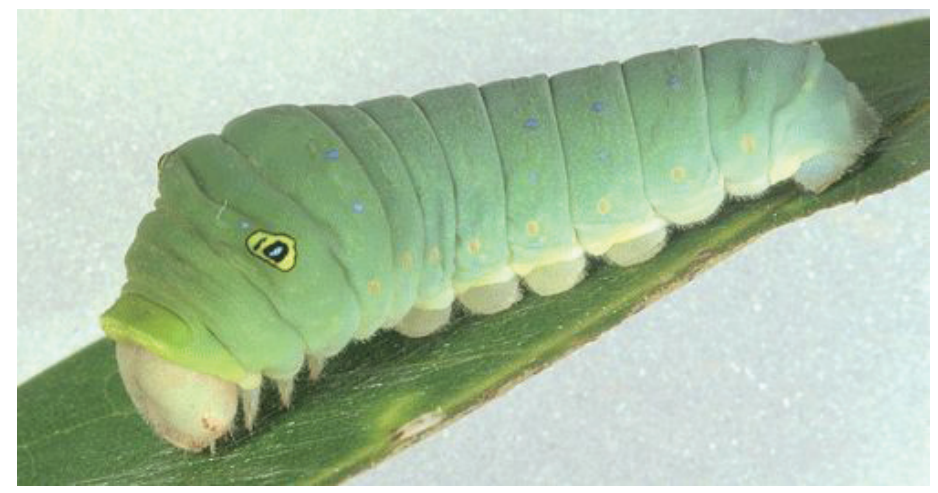

Figure 8. Last instar larva of the tiger swallowtail, Papilio glaucus Linnaeus.

Credits: Jerry F. Butler, UF/IFAS

\section{Pupae}

Pupae are tan with a dark-brown or black lateral stripe and a brown dorsal band (Figure 9).

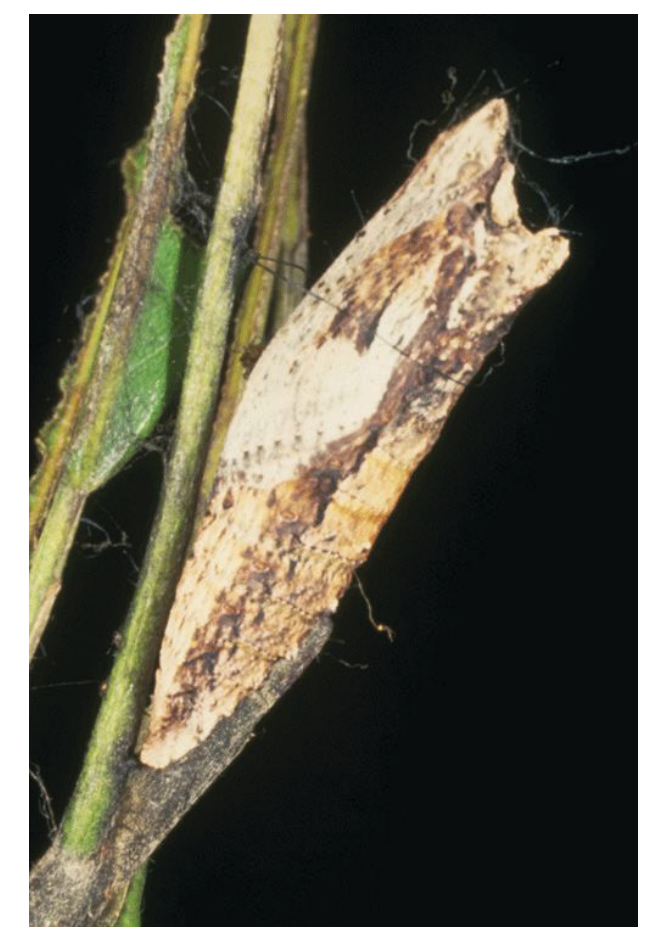

Figure 9. Pupa of the tiger swallowtail, Papilio glaucus Linnaeus. Credits: Jerry F. Butler, UF/IFAS

\section{Life Cycle}

There are two flights in the northern part of the range and at least three and possibly four flights in Florida (Scriber 1996). The first flight in Florida begins in late February or early March. Adults seek nectar at a variety of flowers. They also sip water and minerals from mud (Berger and Lederhouse 1985). Males often patrol at treetop level and swoop to lower levels to intercept females for mating.

Eggs are laid singly and usually on the upper surface of leaves. Newly hatched larvae often eat their egg shells (Scriber 1996). In Lepidoptera eggs, a small quantity of yolk remains trapped between two of the embryonic membranes (amniotic and serosa) that remain inside the egg shells after hatching. The residual yolk serves as the larva's first meal (Imms 1957). This behavior also may reduce detection by predators (Lederhouse 1990), which might be attracted by the empty egg shell.

Larvae spin a mat of silk on a leaf that causes the leaf edges to curl upward, but they do not produce a complete leaf roll. The larva rests on the mat of silk. Mid- to late-instar larvae move from the resting site to other parts of the plant to feed and back to the mat of silk to rest (Scriber 1996).

Chewed leaves are clipped at the petioles and dropped from the plant possibly to reduce attraction of parasitoids that may be drawn to volatile chemicals emanating from the chewed leaves or to reduce predation by birds that locate 
prey by searching for damaged leaves (Lederhouse 1990, Scriber 1996). Larvae throw their frass (feces) with their mandibles. This behavior also may reduce detection by predators or parasitoids (Lederhouse 1990; Scriber et al. 1995).

After full-grown larvae have ceased feeding, they change to greenish-brown or chocolate-brown coloration and wander down tree trunks, usually onto the leaf litter, where they are highly cryptic. They often pupate on the underside of twigs or dead leaves on the ground (West and Hazel 1979). The pupa is the overwintering stage (Minno et al. 2005).

\section{Hosts}

Many species of trees and shrubs in at least seven families are used as hosts (Opler and Malikul 1998, Scott 1986). In peninsular Florida, sweet bay (Magnolia virginiana [L.] [Magnoliaceae]) is the favored host and appears to be the only host in the southern half of the peninsula (Scriber 1986). Sweet bay grows in wet areas and may be distinguished from similar-appearing species of Persea (Lauraceae) by the stipular scars that completely surround the twig (Figure 10) and the glaucous (fine, waxy, whitish coating) undersides of the leaves of Magnolia virginiana (Figure 11 [inset a]) - characteristics that are lacking in species of Persea. In addition, the flowers, fruit and seeds of Magnolia virginiana are distinctive (Figure 11).
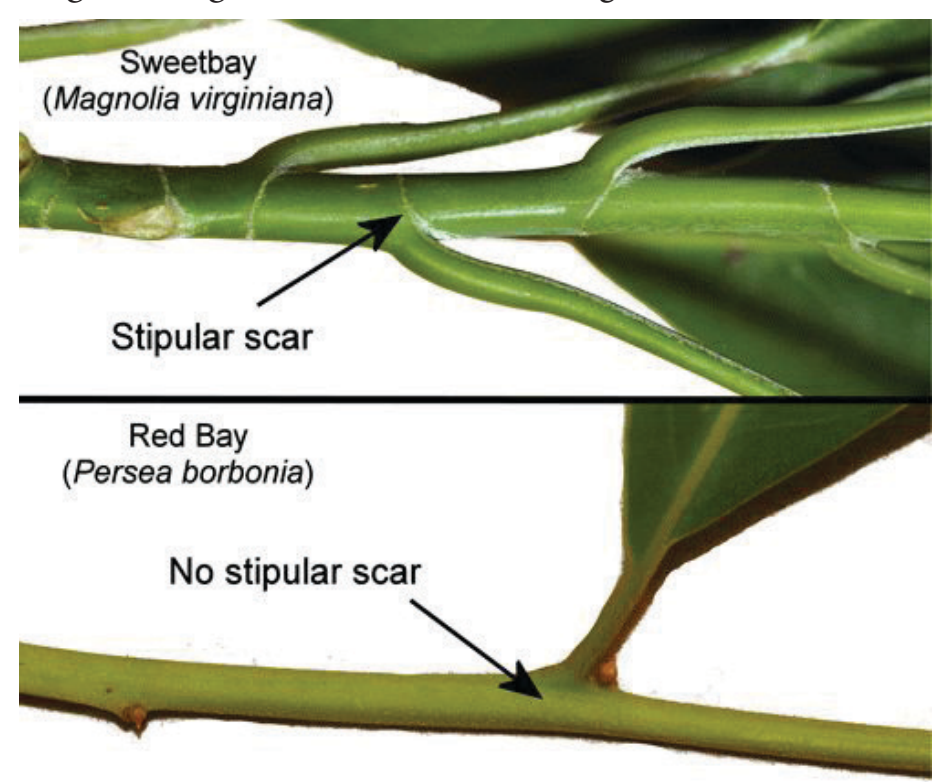

Figure 10. Stems of sweetbay, Magnolia virginiana (L.) (Magnoliaceae) showing stipular scars and the similar-appearing red bay, Persea borbonia that lacks stipular scars. Credits: Donald W. Hall, UF/IFAS

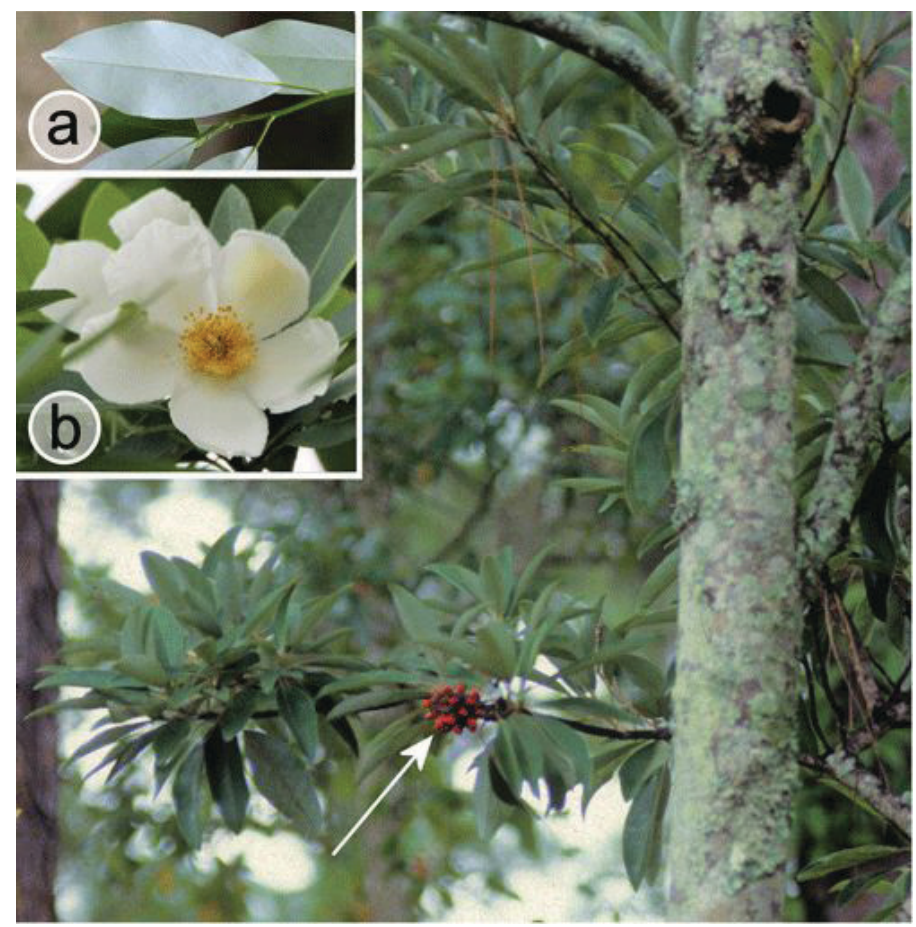

Figure 11. Sweet bay, Magnolia virginiana (L.) (Magnoliaceae) showing characteristic glaucous underside of leaf (inset a), flower (inset b), and seeds (arrow).

Credits: Donald W. Hall, UF/IFAS

Tulip tree, Liriodendron tulipifera Linnaeus (Magnoliaceae) (Figure 12), black cherry, Prunus serotina Ehrh. (Rosaceae) (Figure 13), white ash, Fraxinus americana Linnaeus (Oleaceae) (Figure 14), and pop ash, Fraxinus caroliniana Mill. (Oleaceae), are sometimes used in northern Florida (Minno and Minno 1999). For photographs of Fraxinus caroliniana, see its species page at the Atlas of Florida Plants web site (Wunderlin et al. 2019). Ash trees can be differentiated from the very similar hickories (Carya species) by the opposite arrangement of their leaves on the stems compared to the alternate arrangement of hickory leaves.

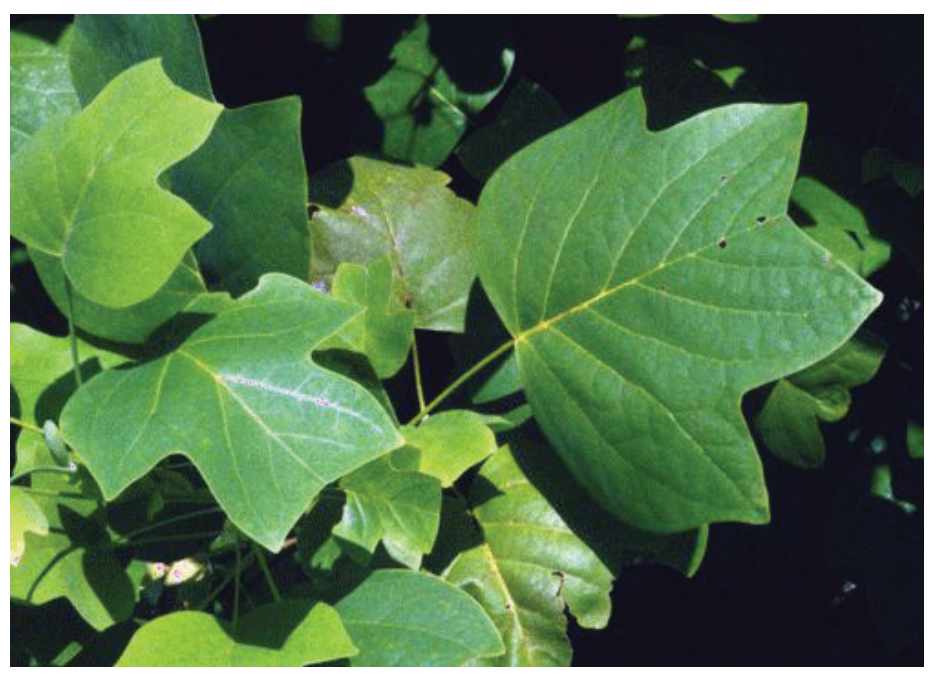

Figure 12. Tulip tree, Liriodendron tulipifera L. (Magnoliaceae) Credits: Donald W. Hall, UF/IFAS 


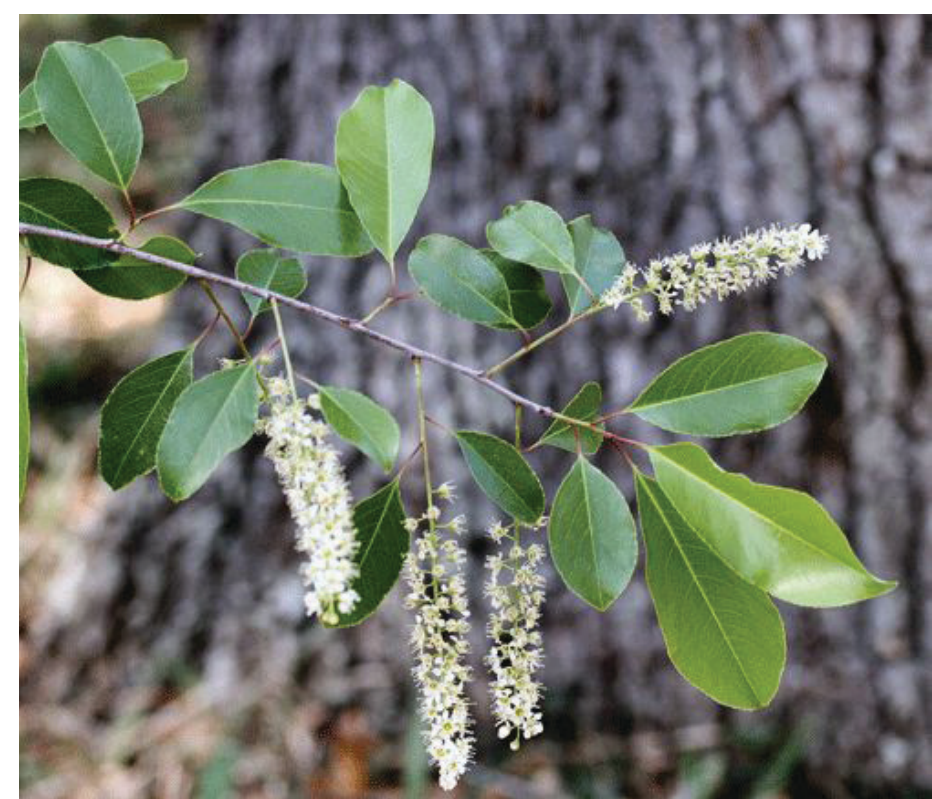

Figure 13. Black cherry, Prunus serotina Ehrh., foliage and flowers. Credits: Jerry F. Butler, UF/IFAS

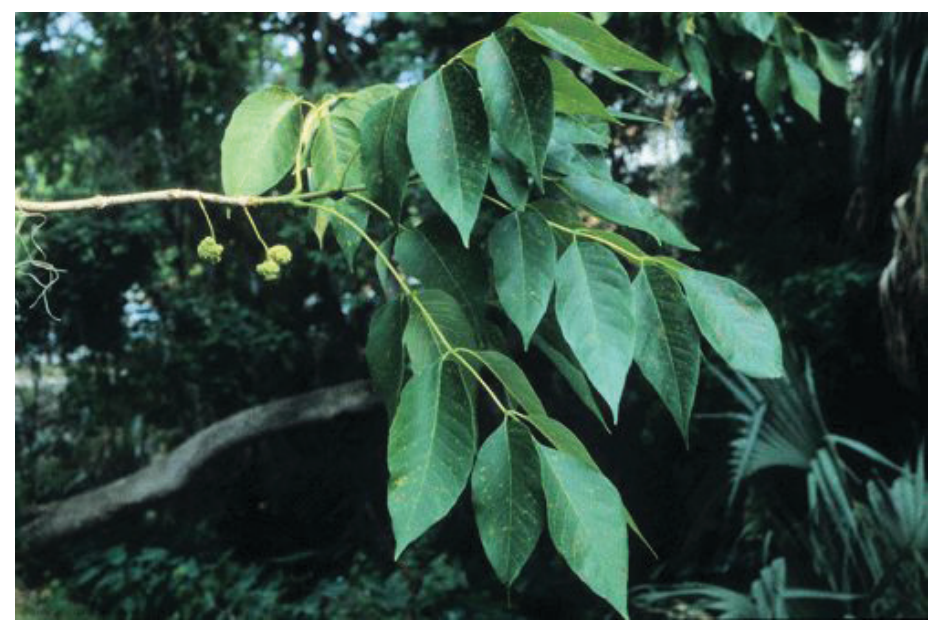

Figure 14. White ash, Fraxinus americana Linnaeus (Oleaceae). Credits: Donald W. Hall, UF/IFAS

\section{Selected References}

Berger TA, and Lederhouse RC. 1985. "Puddling by single male and female tiger swallowtails, Papilio glaucus L. (Papilionidae)." Journal of the Lepidopterists' Society 39:339-340.

Borror DJ. 1960. Dictionary of Word Roots and Combining Forms: Compiled from the Greek, Latin, and other Languages, with Special Reference to Biological and Scientific Names. Palo Alto, CA: Mayfield Publishing Company.

Brower J. 1958. Experimental studies of mimicry in some North American butterflies: Part II. Battus philenor and Papilio troilus, P. polyxenes and P. glaucus. Evolution 12(2): 1239-136.
Emmel J. 1975. Subfamily Papilioninae. pp. 3909-402. In: Howe WH. The Butterflies of North America. Garden City, NY: Doubleday \& Company.

Hagen RH, Lederhouse RC, Bossart JL, adn Scriber JM. 1991. "Papilio canadensis and P. glaucus (Papilionidae) are distinct species." Journal of the Lepidopterists' Society 45(4): 2459-258.

Hancock DL. 1983. "Classification of the Papilionidae (Lepidoptera): A phylogenetic approach.” Smithersia 2:19-48.

Holland WJ. 1949. The Butterfly Book. Garden City, NY: Doubleday \& Company.

Imms AD. 1957. A General Textbook of Entomology: Including the Anatomy, Physiology, Development and Classification of Insects. p. 212. Ninth Edition (entirely revised by Richards OW, Davies RG). Methuen. London. 886 pp.

Miller JS. 1987. "Phylogenetic studies in the Papilioninae (Lepidoptera: Papilionidae)." Bulletin of the American Museum of Natural History 186(4): 3659-512.

Minno M, Butler J, and Hall D. 2005. Florida Butterfly Caterpillars and Their Host Plants. Gainesville, FL: University Press of Florida.

Minno MC, and Minno M. 1999. Florida Butterfly Gardening. Gainesville, FL: University Press of Florida.

Lederhouse RC. 1990. Avoiding the hunt: Primary defenses of lepidopteran caterpillars. pp. 1759-189. In Evans DL, Schmidt JO. (eds). Insect Defenses: Adaptive Mechanisms and Strategies of Prey and Predators. Albany, NY: State University of New York Press.

Opler PA, and Krizek GO. 1984. Butterflies East of the Great Plains. Baltimore, MD: The Johns Hopkins University Press.

Opler PA, and Malikul V. 1998. A Field Guide to Eastern Butterflies. New York, NY: Peterson Field Guides. Houghton Mifflin Company.

Pyle RM. 1981. The Audubon Society Field Guide to North American Butterflies. New York, NY: Alfred A. Knopf.

Scott JA. 1986. The Butterflies of North America. Stanford, CA: Stanford University Press.

Scriber JM. 1986. "Origins of the regional feeding abilities in the tiger swallowtail butterfly: ecological monophagy 
and the Papilio glaucus australis subspecies in Florida." Oecologia 71:949-103.

Scriber JM. 1996. “Tiger tales: natural history of native North American swallowtails." American Entomologist 42:199-32.

Scriber JM, Tsubaki Y, and Lederhouse RC, Eds. 1995. Swallowtail Butterflies: Their Ecology and Evolutionary Biology. Gainesville, FL: Scientific Publishers.

Tyler HA. 1975. The Swallowtail Butterflies of North America. Healdsburg, CA: Naturegraph Publishers.

Tyler HA, Brown KS Jr, and Wilson KH. 1994. Swallowtail Butterflies of the Americas. Gainesville, FL: Scientific Publisher.

Wagner DL. 2005. Caterpillars of Eastern North America. Princeton, NJ: Princeton University Press.

West DA, and Hazel WN. 1979. "Natural pupation sites of swallowtail butterflies (Lepidoptera: Papilionidae): Papilio polyxenes Fabr., P. glaucus L. and Battus philenor (L.)."

Ecological Entomology 4:3879-392.

Wunderlin RP, Hansen BF, Franck AR, and Essig FB. 2019. Atlas of Florida Plants. Institute for Systematic Botany. University of South Florida. Tampa, Florida. (http://www. florida.plantatlas.usf.edu/) (Accessed March 19, 2020) 